\title{
Sonnien lämmönsäätelykäyttäytyminen pihatossa talvella
}

\author{
Leena Tuomisto ${ }^{1)}$, Heidi Lahikainen ${ }^{2)}$, Leena Ahola $^{2)}$, Arto Huuskonen ${ }^{3)}$ ja Risto Kauppinen ${ }^{4)}$ \\ ${ }^{1)}$ Maa- ja elintarviketalouden tutkimuskeskus, Kotieläintuotannon tutkimus, Kuopion yliopisto, Biotie- \\ teiden laitos, PL 1627, 70211 Kuopio, leena.tuomisto@mtt.fi \\ ${ }^{2)}$ Kuopion yliopisto, Biotieteiden laitos, PL 1627, 70211 Kuopio, lahikain@hytti.uku.fi,lee- \\ na.ahola@uku.fi \\ ${ }^{3)}$ Maa- ja elintarviketalouden tutkimuskeskus, Kotieläintuotannon tutkimus, Halolantie 31 A, 71750 \\ Maaninka,arto.huuskonen@mtt.fi \\ ${ }^{4)}$ Savonia-ammattikorkeakoulu, PL 72, 74101, Iisalmi, risto.kauppinen@savonia-amk.fi
}

\section{Tiivistelmä}

Viime vuosina kiinnostus lihanautojen kasvattamiseen eristämättömissä tuotantoympäristöissä, kuten kylmäpihatoissa ja ulkotarhoissa, on lisääntynyt. Eristämättömissä kasvatusoloissa eläimet ovat talvisin alttiina alhaisille lämpötiloille ja lämpötilojen nopeille vaihteluille, mikä asettaa erityishaasteita niiden lämmönsäätelymekanismeille. Lihanautojen lämmönsäätelykäyttäytymistä on tutkittu vain vähän. Tutkimuksemme tarkoituksena oli selvittää ympäristön lämpötilan vaikutusta kasvavien sonnien lämmönsäätelykäyttäytymiseen eristämättömässä pihatossa talvella.

Kokeessa käytettiin 25 hereford-rotuista sonnia, jotka olivat olleet syksystä lähtien eristämättömässä pihatossa osakuivikepohjaisissa ryhmäkarsinoissa (viisi eläintä/karsina, 6,4 $\mathrm{m}^{2} / \mathrm{eläin).} \mathrm{Sonneja}$ videoitiin helmikuussa keskimäärin $399 \mathrm{~kg}$ painoisina. Videonauhoilta valittiin viisi vuorokauden mittaista ajanjaksoa, jotka edustivat eri lämpötiloja, mutta eivät välttämättä olleet peräkkäisinä päivinä. Tarkkailujakso alkoi lämpimillä päivillä (pakkasen purevuus: $-6,4{ }^{\circ} \mathrm{C}$ ensimmäisenä ja $-6,7{ }^{\circ} \mathrm{C}$ toisena tarkkailupäivänä), jonka jälkeen ilma kylmeni $\left(-20,5{ }^{\circ} \mathrm{C}\right.$ kolmantena tarkkailupäivänä) ja lauhtui jälleen hieman $\left(-14,1^{\circ} \mathrm{C}\right.$ neljäntenä ja $-9,6{ }^{\circ} \mathrm{C}$ viidentenä tarkkailupäivänä). Videonauhoilta analysoitiin hetkellisellä seurannalla kymmenen minuutin otantavälillä kunkin sonnin makuuasento ja mahdollinen vartalokontakti toisiin eläimiin. Muuttujat testattiin lineaarisella sekamallilla.

Tarkkailupäivä vaikutti tilastollisesti merkitsevästi $(\mathrm{P}<0,001)$ sonnien kokonaismakuuaikaan sekä kyljellään, käpertyneenä ja vartalokontaktissa toiseen eläimeen vietettyyn aikaan. Sonnit olivat makuulla 58 \pm 1 (keskiarvo \pm keskivirhe), $61 \pm 1,64 \pm 1,56 \pm 1$ ja $61 \pm 1 \%$ havainnoista ensimmäisenä, toisena, kolmantena, neljäntenä ja viidentenä tarkkailupäivänä, vastaavasti. Sonnit makasivat kokonaan kyljellään kaikki jalat ojennettuina suoriksi $3 \pm 1,3 \pm 1,1 \pm 0,1 \pm 0$, ja $2 \pm 0 \%$ makuuhavainnoista ensimmäisenä, toisena, kolmantena, neljäntenä ja viidentenä tarkkailupäivänä, vastaavasti. Sonnit makasivat käpertyneenä rintalastan päällä jalat vartalon alla tai tiukasti vedettyinä vartaloon kiinni $25 \pm 2,19 \pm 1$, $46 \pm 3,32 \pm 3$ ja $40 \pm 2 \%$ makuuhavainnoista ensimmäisenä, toisena, kolmantena, neljäntenä ja viidentenä tarkkailupäivänä, vastaavasti. Sonnit makasivat kiinni toisessa eläimessä $11 \pm 3,10 \pm 2,23 \pm 3,32 \pm 3$ ja $26 \pm 3 \%$ makuuhavainnoista ensimmäisenä, toisena, kolmantena, neljäntenä ja viidentenä tarkkailupäivänä, vastaavasti.

Sonnit reagoivat ympäristön lämpötilan muutokseen käyttäytymistään muuttamalla. Lämpötilan laskiessa sonnit säästivät energiaa makaamalla enemmän kuin lauhempina tarkkailupäivinä. Lisäksi sonnit vähensivät lämmönhukkaansa välttämällä kyljellään makaamista, suosimalla käpertyneenä makaamista sekä hakeutumalla makaamaan vartalokontaktiin toisten eläinten kanssa.

Asiasanat: naudanlihantuotanto, sonnit, kylmäkasvatus, pihatto, käyttäytyminen, lämmönsäätely, lämmönhukka, makuuasento, huddling 


\section{Johdanto}

Viime vuosina kiinnostus lihanautojen kasvattamiseen eristämättömissä tuotantoympäristöissä, kuten kylmäpihatoissa ja ulkotarhoissa on lisääntynyt (Huuskonen ym. 2002). Käytännön kokemukset ja tutkimukset osoittavat, että huolellisesti toteutettuna ulkokasvatus ei vaaranna lihanautojen hyvinvointia tai kasvua (Lehtiniemi ym. 2001, Huuskonen ym. 2002, 2004). Eristämättömissä kasvatusoloissa eläimet ovat talvisin alttiina alhaisille lämpötiloille ja lämpötilojen nopeille vaihteluille, mikä asettaa erityishaasteita niiden lämmönsäätelymekanismeille.

Kasvavat naudat kestävät yleisesti hyvin kylmää ja sietävät alhaisia lämpötiloja paremmin kuin esimerkiksi vasikat tai ihminen (Young 1981, Tirri ym. 1995). Termoneutraalialueella tasalämpöisen eläimen ei tarvitse käyttää aineenvaihdunnallisia mekanismeja lämpötilansa säätelyyn, vaan siihen riittävät lämmönhukkaa säätelevät mekanismit (Tirri ym. 1995). Termoneutraalin alueen alarajalla sijaitsee alempi kriittinen lämpötila, joka vaihtelee olosuhteiden ja eläimen kunnon mukaan. Esimerkiksi $350 \mathrm{~kg}$ painavien lihanautojen, joiden päiväkasvu on $1,3 \mathrm{~kg}$, alempi kriittinen lämpötila lähes tyynellä on $-26^{\circ} \mathrm{C}$ (Webster 1974). Kylmässä eläin ensisijaisesti pienentää lämmönhukkaansa, mutta ympäristön lämpötilan laskiessa alemman kriittisen lämpötilan alle eläimen on lisäksi lisättävä lämmöntuottoaan lisäämällä aineenvaihduntaansa (Young 1981, 1983, Wagner 1988).

Eläimet käyttävät lämmönhukkansa pienentämiseen fysiologisia ja käyttäytymiseen liittyviä mekanismeja. Fysiologisia mekanismeja ovat ihon pintaverisuonten supistuminen ja karvapeitteen pörhistäminen (Tirri ym. 1995). Käyttäytymismekanismeja puolestaan ovat "käpertyminen", ts. naudoilla makuuasennossa raajojen pitäminen tiukasti vartaloa vasten (autohuddling), sosiaalinen lämmönsäätely eli hakeutuminen tiiviiseen vartalokontaktiin toisen eläimen kanssa (allohuddling), suojaan hakeutuminen sekä eristävän makuualustan valinta (Tirri ym. 1995, Kauppinen 2000).

Lihanautojen lämmönsäätelykäyttäytymistä on tutkittu vain vähän. Tutkimuksemme tarkoituksena oli selvittää ympäristön lämpötilan vaikutusta kasvavien sonnien lämmönsäätelykäyttäytymiseen eristämättömässä pihatossa talvella.

\section{Aineisto ja menetelmät}

Tutkimus tehtiin Maa- ja elintarviketalouden tutkimuskeskuksen (MTT) Ruukin toimipisteessä helmikuussa 2005. Tutkimuksessa käytettiin 25 hereford-rotuista sonnia, jotka olivat syntyneet MTT:n Tohmajärven emolehmänavetassa keväällä 2004 ja olleet kesän laitumella emojensa kanssa. Eläimet siirrettiin syksyllä 2004 Ruukkiin eristämättömään pihattoon ryhmäkarsinoihin (4 x 8 m). Kussakin karsinassa oli viisi eläintä (6,4 m²/eläin). Karsinan takaosa oli kuivitettu oljella makuualueeksi ja etuosassa sijaitsi betonipohjainen lantakäytävä. Karsinan etuosassa sijaitsevalla ruokintakaukalolla oli syöntitilaa $70 \mathrm{~cm} /$ eläin. Sonneja ruokittiin vapaasti seosrehulla, jonka kuiva-aineesta $60 \%$ oli nurmisäilörehua ja 40 \% väkirehua (ohrarehua ja ohraa). Kivennäislisä oli 150 g/sonni/vrk.

Sonnien käyttäytymistä havainnoitiin helmikuussa videoimalla jokaista karsinaa. Sonnit olivat videoinnin aikana keskimäärin 10 kk ikäisiä ja 399 kg painoisia. Jokaisen karsinan yläpuolelle kiinnitettiin videokamera, joka kuvasi pelkästään karsinan makuualuetta. Edellisten vuosien kokemusten perusteella oletettiin, että sonnit makaavat ainoastaan kuivitetulla makuualueella. Jokaisen karsinan makuualueen yläpuolelle ripustettiin $60 \mathrm{~W}$ hehkulamppu mahdollistamaan yötarkkailun. Videonauhoilta valittiin viisi vuorokauden mittaista ajanjaksoa, jotka edustivat eri lämpötiloja, mutta eivät välttämättä olleet peräkkäisinä päivinä (Taulukko 1). Tarkkailupäivien aikana oli tyyntä tai tuuli oli heikkoa. Vallitseva tuulen suunta oli usein kaakon suunnasta eli pihaton avointa sivua kohden. Tämän vuoksi määritettiin pakkasen purevuus, mikä kuvastaa lämpötilan ja tuulen yhdysvaikutusta (Ilmatieteen laitos 2007). Tarkkailujakson kaksi ensimmäistä päivää olivat lämpimimmät (pakkasen purevuus: $-6,4$ ja $\left.-6,7^{\circ} \mathrm{C}\right)$. Kolmas tarkkailupäivä oli kylmin $\left(-20,5^{\circ} \mathrm{C}\right)$, jonka jälkeen ilma lauhtui hieman $(-14,1$ ${ }^{\circ} \mathrm{C}$ neljäntenä ja $-9,6^{\circ} \mathrm{C}$ viidentenä tarkkailupäivänä).

Analysoitavat ajanjaksot valittiin alkaviksi makuualueen kuivituksesta, jotta makuualueen kunto olisi mahdollisimman samanlainen kaikkina tarkkailuvuorokausina. Videonauhoilta analysoitiin hetkellisellä seurannalla (katso Martin \& Bateson 1993) kymmenen minuutin otantavälillä kunkin sonnin makuuasento ja mahdollinen vartalokontakti toisiin eläimiin (Taulukko 2). Sosiaalisen lämmönsäätelyn voimakkuuden määrittämiseksi eläimen vartalon kumpikin sivu jaettiin kolmeen yhtä suureen osaan (yhteensä 6 osaa/eläin). 
Taulukko 1. Käyttäytymistarkkailujen ajankohdat ja niiden sääolosuhteet ${ }^{1}$.

\begin{tabular}{ccccccc}
\hline Pvm. & $\begin{array}{c}\text { Lämpötila } \\
\left({ }^{\circ} \mathrm{C}\right) \mathrm{ka} .\end{array}$ & $\begin{array}{c}\text { Lämpötila } \\
\left({ }^{\circ} \mathrm{C}\right) \mathrm{min}\end{array}$ & $\begin{array}{c}\text { Lämpötila } \\
\left({ }^{\circ} \mathrm{C}\right) \mathrm{max}\end{array}$ & $\begin{array}{c}\text { Tuulen } \\
\text { nopeus }(\mathrm{m} / \mathrm{s}) \\
\text { ka. }\end{array}$ & $\begin{array}{c}\text { Pakkasen } \\
\text { purevuus } \\
\text { ka. }\end{array}$ & $\begin{array}{c}\text { Vallitseva } \\
\text { tuulen } \\
\text { suunta }\end{array}$ \\
\hline 11.2.-12.2. & $-3,1$ & $-6,0$ & 0,0 & 2,1 & $-6,4$ & etelä-lounas \\
12.2.-13.2. & $-4,0$ & $-6,5$ & $-1,8$ & 1,7 & $-6,7$ & kaakko \\
15.2.-16.2. & $-20,1$ & $-25,5$ & $-13,2$ & 0,5 & $-20,5$ & $\begin{array}{c}\text { pohjoinen ja } \\
\text { kaakko }\end{array}$ \\
17.2.-18.2. & $-9,4$ & $-15,6$ & $-6,7$ & 2,4 & $-14,1$ & etelä-kaakko \\
18.2.-19.2. & $-5,0$ & $-6,5$ & $-3,7$ & 3,0 & $-9,6$ & kaakko \\
\hline
\end{tabular}

${ }^{1}$ Säätiedot saatiin MTT Ruukin toimipisteessä sijaitsevalta sääasemalta.

Tilastollinen testaus tehtiin SPSS for Windows 14.0 -ohjelmalla. Muuttujat analysoitiin lineaarisella sekamallilla, jonka yleinen muoto oli:

$Y_{i j k}=\mu+\beta_{i}+\gamma_{j}+\varepsilon_{i j k}$

jossa $Y_{i j k}=$ käyttäytymistoiminnon osuus havainnoista, $\mu=$ yleiskeskiarvo, $\beta_{i}=$ tarkkailupäivän $i$ kiinteä vaikutus, $\gamma_{j}=$ karsinan $j$ satunnaisvaikutus ja $\varepsilon_{i j k}=$ virhetermi. Mallissa käytettiin toistomittausten kovarianssirakennetta (TPH, UN, TP tai ARH(1)), joka valittiin Akaiken informaatiokriteerin perusteella. Pareittaisvertailuissa käytettiin P-arvojen Bonferroni-korjausta. Muuttujalle makaa kyljellään tehtiin Box-Cox -muuttujamuunnos, koska sen virhetermien normaalijakaumaolettamus ja varianssien homogeenisyysolettamus eivät toteutuneet. Muuttujat sosiaalinen lämmönsäätely 2/6 vartalosta sekä sosiaalinen lämmönsäätely 3/6-4/6 vartalosta testattiin parametrittomalla Friedmanin testillä, koska muuttujat eivät muuttujamuunnoksenkaan jälkeen sopineet testattaviksi sekamallilla.

Taulukko 2. Käyttäytymistoimintojen kuvaukset.

\begin{tabular}{ll}
\hline Toiminto & Kuvaus \\
\hline Makaa & Makaa missä tahansa asennossa vartalo kontaktissa maahan. \\
Makaa kyljellään & $\begin{array}{l}\text { Makaa kokonaan toisella kyljellään. Kaula ja jalat ovat ojennettuina ja pää on maassa } \\
\text { tai koholla. }\end{array}$ \\
$\begin{array}{l}\text { Makaa käpertyneenä } \\
\text { (autohuddling) }\end{array}$ & $\begin{array}{l}\text { Makaa rintalastan päällä jalat vartalon alla tai tiukasti vedettyinä vartaloon kiinni. } \\
\text { Makaa muussa ma- } \\
\text { kuuasennossa }\end{array}$ \\
$\begin{array}{l}\text { Sosiaalinen lämmön- } \\
\text { säätely (allohuddling) }\end{array}$ & $\begin{array}{l}\text { Makaa muussa asennossa kuin kyljellään tai käpertyneenä. Yleisimmin makaa rinta- } \\
\text { pinta-alalta. }\end{array}$ \\
\hline
\end{tabular}

\section{Tulokset ja tulosten tarkastelu}

Tarkkailujakson aikana sonnien havaittiin makaavan ainoastaan kuivitetulla makuualueella. Kuivitettu makuualue selvästi tarjosi eläimille miellyttävän, eristävän ja pehmeän makuualustan. Sonnien makuulla viettämässä ajassa ei ollut eroa kahden ensimmäisen tarkkailupäivän välillä (Kuva 1). Kolmantena eli kylmimpänä tarkkailupäivänä makuulla vietetty aika lisääntyi ensimmäiseen tarkkailupäivään verrattuna. Tulos on yhtenevä Gonyoun ym. (1979) ja Redbon ym. (1996) tutkimusten kanssa, joissa härkien havaittiin makaavan enemmän kylmällä säällä. Redbon ym. (1996) mukaan passiivisuus alhaisissa lämpötiloissa voi olla eläimen kannalta hyvä käyttäytymisstrategia, koska siten eläin pystyy säästämään energiaa ja lämpöä. Kylmän päivän jälkeinen tarkkailupäivä oli edelleen hyvin kylmä, mutta siitä huolimatta sonnit makasivat silloin vähiten. Syy tähän on epäselvä.

Makuuasennoista kylkiasennossa naudan lämmönhukka on suurimmillaan, koska tällöin nauta ojentaa kaikki jalkansa suoriksi ja paljastaa vatsansa, jolloin vartalon ilman kanssa kosketuksissa oleva pinta-ala on suurimmillaan. Tutkimuksessamme sonnit makasivat vähemmän kyljellään kolmantena eli kylmimpänä tarkkailupäivänä kuin sitä edeltävinä lämpiminä päivinä (Kuva 2a), mikä oli eläinten lämmönsäätelyn kannalta järkevää. Kylmintä päivää seuraavina päivinä ilman alkaessa lauhtua kyljellään makaaminen jälleen lisääntyi ja palasi kylmintä päivää edeltävälle tasolle. Ympäristön lämpötilal- 
la on havaittu olevan vaikutusta kyljellään makaamisen määrään myös vasikoilla. Hänninen ym. (2003) havaitsivat kylmäkasvatettujen vasikoiden makaavan vähemmän kyljellään kuin sisällä kasvatettujen vasikoiden.

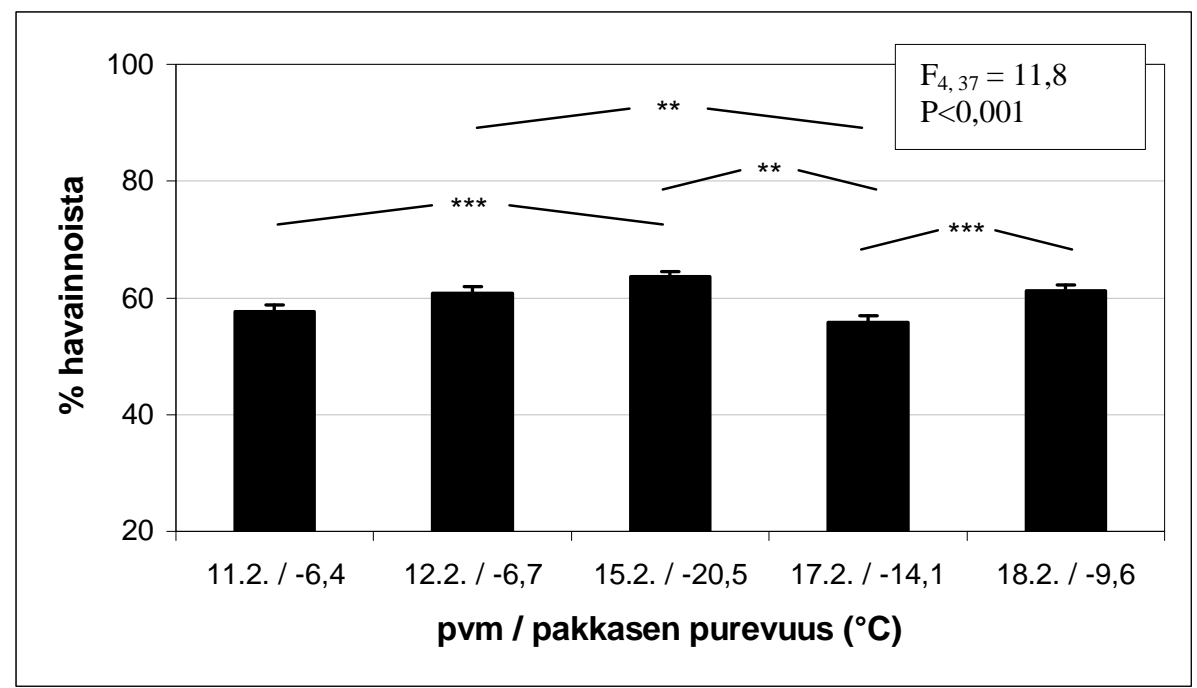

Kuva 1. Sonnien makuulla viettämä aika prosentteina kaikista havainnoista eri tarkkailuvuorokausina (keskiarvo \pm keskivirhe). Tilastollinen merkitsevyys: $* * \mathrm{P}<0,01, * * * \mathrm{P}<0,001$.

Käpertyneenä maatessaan nauta vetää jalkansa vartalonsa alle tai pitää ne tiukasti kiinni vartalossaan vähentäen raajoista tapahtuvaa lämmönhukkaa. Vasikoilla käpertyneenä makaamisen on todettu lisääntyvän kylmässä (Gonzalez-Jimenez 1962, Kauppinen 2000). Toisaalta Bøe ja Havrevoll (1993) eivät havainneet lämpötilan vaikuttavan vasikoiden jalkojen asentoon makuulla. Tutkimuksessamme käpertyneenä makaaminen näytti kuitenkin toimivan lämmönhukan vähentämisstrategiana myös sonneilla. Sonnit makasivat enemmän käpertyneenä kolmantena eli kylmimpänä tarkkailupäivänä kuin sitä edeltävinä lämpiminä päivinä (Kuva 2b). Vaikka kylmän päivän jälkeinen tarkkailupäivä oli edelleen hyvin viileä, käpertyneenä makaaminen vähentyi huomattavasti. Tämä voi selittyä sosiaalisen lämmönsäätelyn suurella määrällä kyseisenä päivänä (Kuva 3), mikä saattoi vähentää sonnien tarvetta maata käpertyneenä.

Muussa makuuasennossa maatessaan sonni makasi yleensä rintalastansa päällä yksi tai useampi jalka osittain tai kokonaan ojennettuna, jolloin asentoa voidaan pitää ääripäiden, kyljellään ja käpertyneenä makaamisen, välimuotona lämmönhukan määrällä arvioituna. Kyljellään ja käpertyneenä makaamisen määrien vaihtelut eri tarkkailupäivinä heijastuivat muussa makuuasennossa makaamisen osuuteen makuuhavainnoista (Kuva 2c). Siten sonnit makasivat muussa makuuasennossa vähiten kylmimpänä tarkkailupäivänä sekä viimeisenä tarkkailupäivänä.

Makaaminen vartalokontaktissa toisen eläimen kanssa lisääntyi kolmantena eli kylmimpänä tarkkailupäivänä verrattuna kahteen ensimmäiseen tarkkailupäivään, ja oli suurimmillaan neljäntenä tarkkailupäivänä (Kuva 3). Ei ole selvää, miksi sosiaalisen lämmönsäätelyn osuus oli suurimmillaan vasta kylmimmän tarkkailupäivän jälkeen. Suurin osa sosiaalisesta lämmönsäätelystä oli vähäistä käsittäen 1/6 vartalon pinta-alasta. Vartalokontaktia 2/6 havaittiin vähemmän, ja 3/6-4/6 kontaktia vain yksittäisiä kertoja. Kylmällä säällä sonnien on järkevää hakeutua vartalokontaktiin toistensa kanssa pienentääkseen lämmönhukkaansa. Myös vasikoilla makaamisen vartalokontaktissa toiseen eläimeen on havaittu lisääntyvän lämpötilan laskiessa (Bøe \& Havrevoll 1993, Kauppinen 2000). 
a)

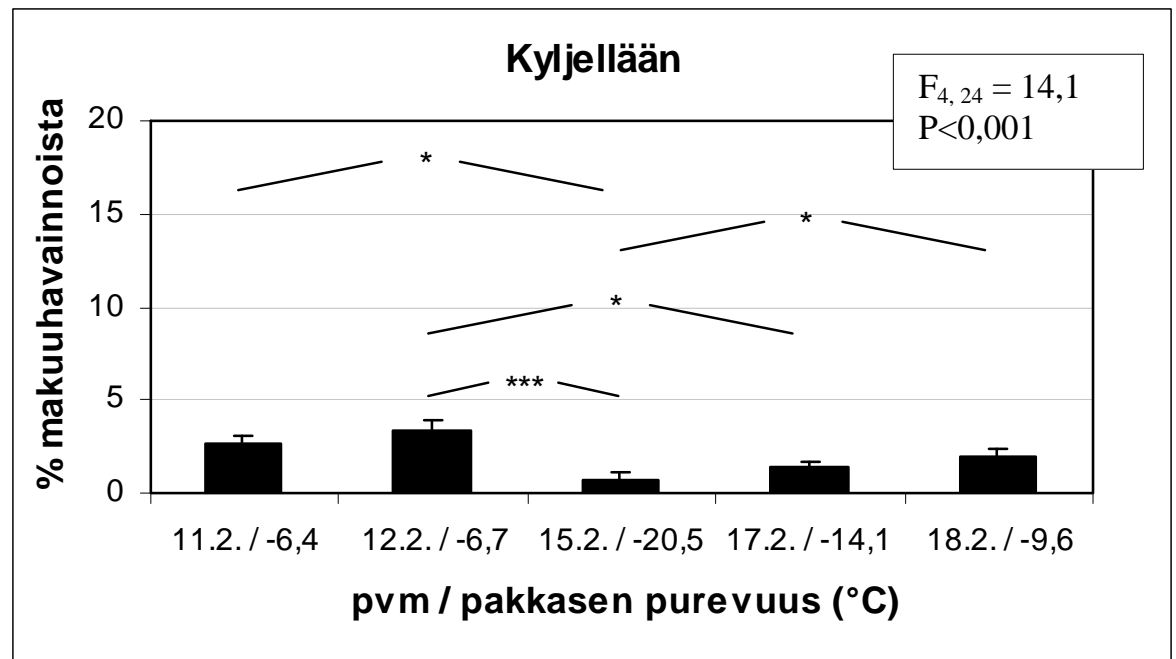

b)

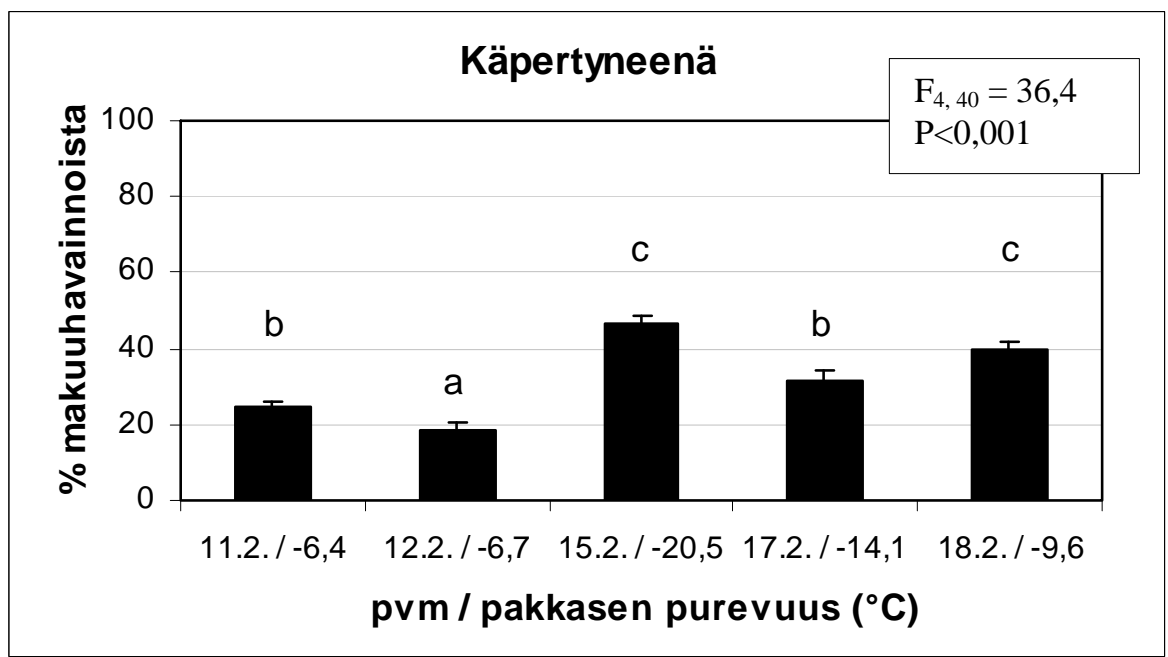

c)

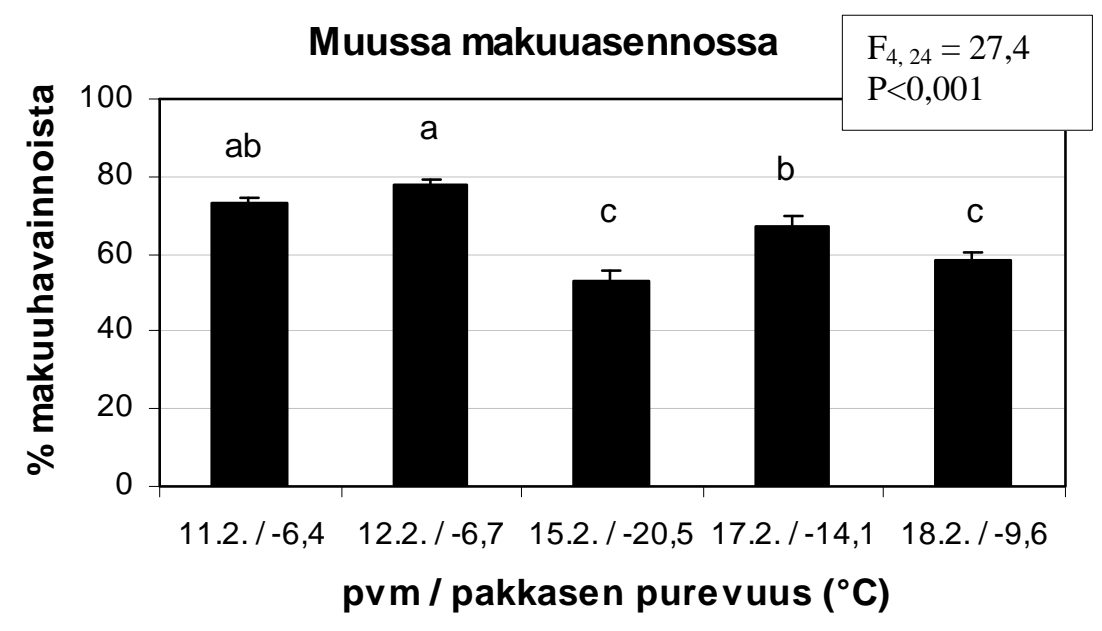

Kuva 2. Sonnien kyljellään (a), käpertyneenä (b) sekä muussa makuuasennossa (c) viettämä aika prosentteina makuuhavainnoista eri tarkkailuvuorokausina (keskiarvo \pm keskivirhe). Tilastollinen merkitsevyys: * $\mathrm{P}<0,05$, *** $\mathrm{P}<0,001$. Eri kirjaimet (a, b, c, d) tarkoittavat, että tarkkailupäivät eroavat kyseessä olevan käyttäytymistoiminnon osalta tilastollisesti merkitsevästi $(\mathrm{P}<0,05)$ toisistaan. 


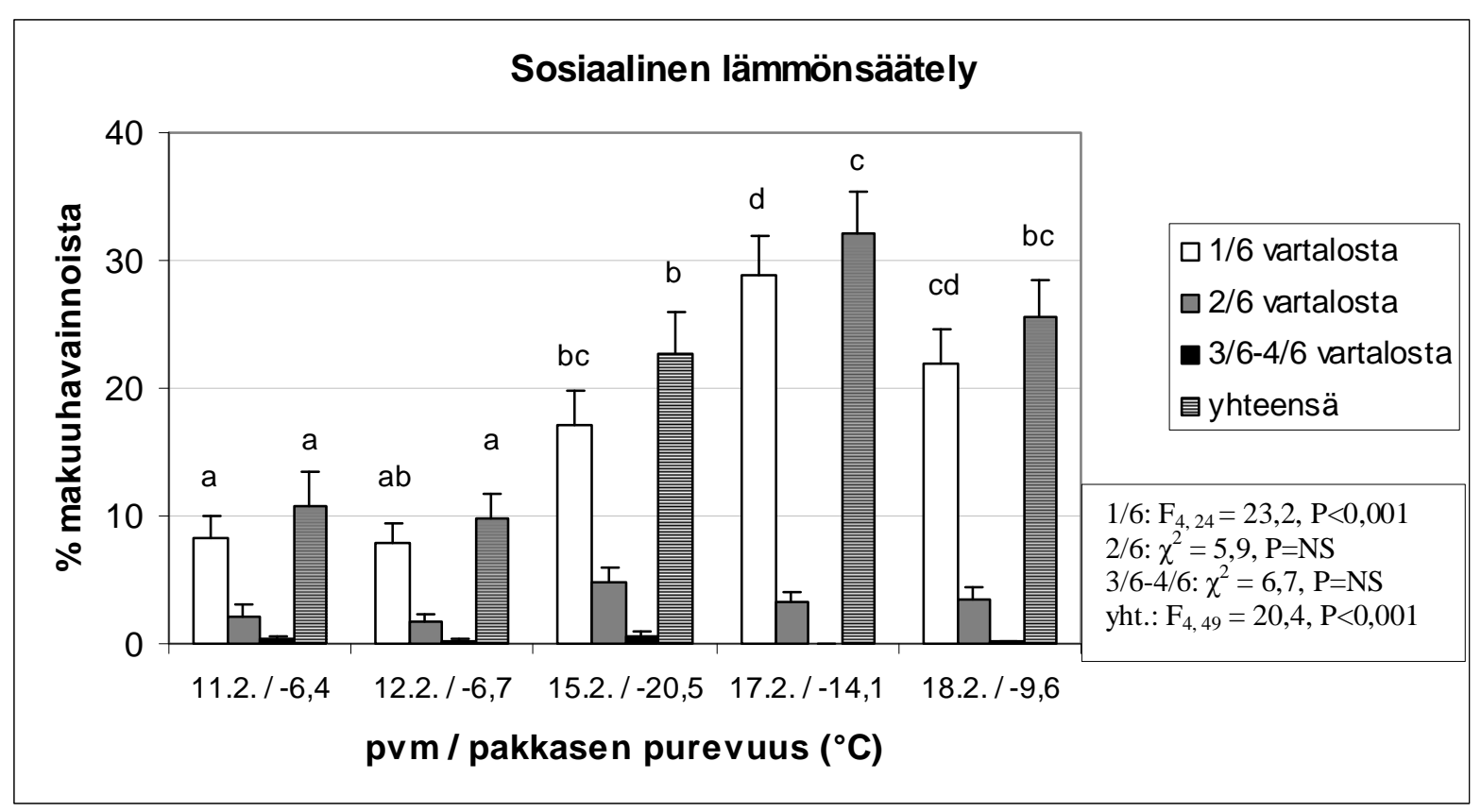

Kuva 3. Sosiaalisen lämmönsäätelyn osuus prosentteina sonnien makuulla viettämästä ajasta eri tarkkailuvuorokausina (keskiarvo \pm keskivirhe). Eri kirjaimet (a, b, c, d) tarkoittavat, että tarkkailupäivät eroavat kyseessä olevan käyttäytymistoiminnon osalta tilastollisesti merkitsevästi $(\mathrm{P}<0,05)$ toisistaan.

\section{Johtopäätökset}

Eristämättömässä pihatossa kasvatetut sonnit reagoivat ympäristön lämpötilan muutokseen käyttäytymistään muuttamalla. Lämpötilan laskiessa sonnit säästivät energiaa makaamalla enemmän. Lisäksi sonnit vähensivät lämmönhukkansa välttämällä kyljellään makaamista, suosimalla käpertyneenä makaamista sekä hakeutumalla makaamaan vartalokontaktiin toisten eläinten kanssa.

\section{Kirjallisuus}

Bøe, K. \& Havrevoll, Ø. 1993. Cold housing and computer-controlled milk feeding for dairy calves: behaviour and performance. Anim. Prod. 57: 183-191.

Gonyou, H.W., Christopherson, R.J. \& Young, B.A. 1979. Effects of cold temperature and winter conditions on some aspects of behaviour of feedlot cattle. Appl. Anim. Ethol. 5: 113-124.

Gonzalez-Jimenez, E. \& Blaxter, K.L. 1962. The metabolism and thermal regulation of calves in the first month of life. Br. J. Nutr. 16: 199-212.

Huuskonen, A., Honkavaara, M. \& Joki-Tokola, E. 2004. Kylmän kasvatusympäristön vaikutus ay-rotuisten lihanautojen tuotantotuloksiin ja lihan laatuun. Teoksessa: Anneli Hopponen ja Marketta Rinne (toim.). Maataloustieteen Päivät 2004, 12.-13.1.2004 Viikki, Helsinki [esitelmät ja posterit]. Suomen maataloustieteellisen seuran tiedote $19.4 \mathrm{~s}$.

Huuskonen, A., Joki-Tokola, E. \& Huttu, S. 2002. Lihanautojen kasvatus kylmissä tuotantoympäristöissä. Teoksessa: Marketta Rinne (toim.). Maataloustieteen Päivät 2002: Kotieläintiede. Maaseutukeskusten Liiton julkaisuja 977: 36-39.

Hänninen, L., Hepola, H., Rushen, J., De Passille, A.M., Pursiainen, P., Tuure, V.-M., Syrjälä-Qvist, L., Pyykkönen, M. \& Saloniemi, H. 2003. Resting behaviour, growth and diarrhoea incidence rate of young dairy calves housed individually or in groups in warm or cold buildings. Acta Agric. Scand. Sect. A Anim. Sci. 53: 2128.

Ilmatieteen laitos 2007. Pakkasen purevuus. http://www.fmi.fi/saa/index_7.html. Viitattu 21.11.2007.

Kauppinen, R. 2000. Acclimatization of dairy calves to a cold and variable micro-climate. Kuopion yliopiston julkaisuja C. Luonnontieteet ja ympäristötieteet 113. Kuopio: Kuopion yliopisto.

Lehtiniemi, T., Perälä, M. \& Holmström, S. 2001. Havaintoja ulkokasvatustiloilta. Oulu: Oulun Maaseutukeskus. $16 \mathrm{~s}$.

Martin, P. \& Bateson, P. 1993. Measuring behaviour. An introductory guide. Toinen painos. UK: Cambridge University press. $222 \mathrm{~s}$.

Redbo, I., Mossberg, I., Ehrlemark, A. \& Ståhl-Högberg, M. 1996. Keeping growing cattle outside during winter: behaviour, production and climatic demand. Anim. Sci. 62: 35-41. 
Tirri, R., Lehtonen, J., Lemmetyinen, R., Pihakaski, S. \& Portin, P. 1995. Biologian sanakirja. Helsinki: Otava. $607 \mathrm{~s}$.

Wagner, D.G. 1988. Effects of cold stress on cattle performance and management factors to reduce cold stress and improve performance. The Bov. Pract. 23: 88-93.

Webster, A.J.F. 1974. Heat loss from cattle with particular emphasis on the effects of cold. Teoksessa: Monteith, J.L. \& Mount, L.E. (toim.). Heat loss from animals and man: assessment and control. Proceedings of the Twentieth Easter School in agricultural science, University of Nottingham 1973. Lontoo: Butterworths. s. 205231.

Young, B.A. 1981. Cold stress as it affects animal production. J. Anim. Sci 52: 154-163.

Young, B.A. 1983. Ruminant cold stress: Effect on production. J. Anim. Sci. 57: 1601-1607. 